\title{
Making of the Moment Something Permanent: Character and Virginia Woolf's
} Moment of Being

\author{
Brooke Lockwood Lestock \\ Fort Lauderdale, Florida
}

Bachelor of Arts, University of Florida, 2008

A Thesis presented to the Graduate Faculty of the University of Virginia in Candidacy for the Degree of Master of Arts

\section{Department of English}

\section{University of Virginia}

May, 2012

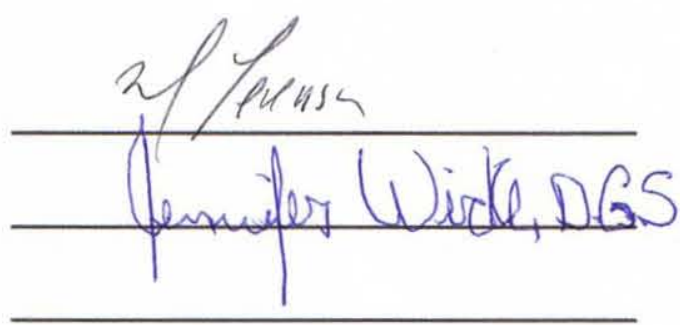


In Virginia Woolf's autobiographical essay "A Sketch of the Past,"1 Woolf attempts to explain her own "psychology" by dividing life into two states of existence: being and non-being. "A great part of every day is not lived consciously," she writes, and she characterizes this state of non-being as consisting of forgettable moments ("I have already forgotten what Leonard and I talked about at lunch") that comprise "a kind of nondescript cotton wool" in which moments of being are embedded (70). The cotton wool of non-being which envelops most of daily existence is then spontaneously ruptured by "sudden shocks," "exceptional moments" that reveal the pattern hidden behind the cotton wool, "some real thing behind appearances," and imprint themselves upon the memory (70). For Woolf, the shock is always followed by a desire to explain the experience in writing:

I make it real by putting it into words. It is only by putting it into words that I make it whole; it gives me, perhaps because by doing so I take away the pain, a great delight to put the severed parts together ... It is the rapture I get when in writing I seem to be discovering what belongs to what; making a scene come right; making a character come together. (72)

Jeanne Schulkind, in her introduction to Moments of Being, the collection of autobiographical writings in which "A Sketch of the Past" appears, places the moment of being, the "privileged moment when a spiritually transcendent truth of either personal or cosmic dimensions is perceived," within a long tradition of idealist and mystical philosophies extending from Plato to Henri Bergson, but as Schulkind observes, its most direct literary influences can be located within James Joyce's notion of the epiphany and William Wordsworth's idea of the "spontaneous overflow of emotion" which is then

\footnotetext{
${ }^{1}$ Written from April 1939 to November 1940 and published posthumously by Leonard Woolf.
} 
"recollected in tranquillity" (Schulkind 17). Schulkind differentiates Woolf's privileged moment in that the Woolfian philosophy is set in a "uniquely personal context ... emerging, almost inevitably, from her own intense and highly individual susceptibility" (17). But even though Woolf has been called "the most inward of all British writers" (North 81), Woolf's moment of being is not a mere looking-inward or sublimation of the susceptible self that might be seen as typical of modernist solipsism, but is instead an act of seeking and discovering knowledge about the life of another. Though it does emerge as a result of Woolf's "highly individual susceptibility," it is as much a narrative act as it is a personal experience, and so in order to represent both the personal and cosmic dimensions of the moment, Woolf privileged the realistic and truthful representation of character above all other authorial concerns. Before the pattern behind the cotton wool of daily life can be revealed, character must "come together," to use Woolf's words. Though Woolf's notion of the moment of being has become, as Michael Levenson notes in Modernism and the Fate of Individuality, "worn intellectual property" (208), in this essay, I will examine the moment of being in three specific novels, Night and Day, Mrs. Dalloway, and To the Lighthouse in order to better understand how the moment of being, particularly its expression through characters, evolves alongside Woolf's development as a novelist. Beginning with the novel that Woolf designated as her first attempt at conveying non-being (Night and Day) and ending with the novel that represents the successful and complete expression of the moment of being (To the Lighthouse), I will demonstrate what I see as three distinct phases in the development of the moment from the personal to the social to the cosmic dimensions of existence, becoming ever more nuanced and more urgent for Woolf. First, however, it will be necessary to better 
understand Woolf's particular conception of character, a subject that is absolutely integral to any discussion of Woolf's writing philosophy.

Joan Bennett, in Virginia Woolf: Her Art as a Novelist, argues that the moment of being is "a heightened consciousness in which superficial differences of character are submerged beneath the tide of feeling" (8). In Bennett's view, the particularities of an individual character, what makes him or her "real," are subordinate to and even detachable from, the "deep and simple human experiences" that Woolf represents in her fiction (3). She claims that in The Voyage Out and in Night and Day "what the readers feel is not so much 'this man or woman would have felt like that in those circumstances,' but rather 'Yes, that is how it feels to be in love; to be happy; to be desolate" (3). But Bennett's description of Woolf's "art as a novelist" ignores what Woolf herself set forth in numerous venues - including multiple essays, diary entries, correspondences, and short fiction - as her own philosophy of fiction, which is perhaps best illustrated in the following passage from "Mr. Bennett and Mrs. Brown," a lecture-turned-essay she delivered to the Heretics Society at Cambridge in May of 1924:

I believe that all novels begin with an old lady in the corner opposite. I believe that all novels, that is to say, deal with character, and that it is to express character - not to preach doctrines, sing songs, or celebrate the glories of the British Empire, that the form of the novel, so clumsy, verbose, and undramatic, so rich, elastic, and alive, has been evolved. (102) Woolf's problem with the state of writing, both biographical and fictional, is that time and again writers fail to "look at life." In "Mr. Bennett and Mrs. Brown," the Edwardian novelists (Wells, Bennett, and Galsworthy, as Woolf lists them) are the perpetrators of 
this failing to look at life; when they are face-to-face with character, the old lady in the train whom Woolf dubs Mrs. Brown, they choose to describe Mrs. Brown's home, her father's occupation, the "wages of shop assistants in the year 1878," what her mother died of, etc. (112). They look out the window of the railway car for details and facts, "but never at her, never at life, never at human nature" (110). Woolf agrees with Arnold Bennett when he says, "The foundation of good fiction is character-creating and nothing else ... If the characters are real the novel will have a chance" (qtd. on 94-95), and she goes on to define "real" character as having the ability "to make you think not merely of it itself, but of all sorts of things through its eyes" (103). The quest for Mrs. Brown runs parallel to or even on the same route as the quest for reality because, as Jeanne Schulkind observes, the questions posed by Woolf's characters - What is life? What is love? What is reality? Who are you? Who am I? - lead to this one end, "the spiritual continuum which embraces all of life" (Schulkind 18). Character and human experience are inseparable for Woolf because the reader cannot feel for or with Mrs. Brown if the reader does not know who she is, is not able to see through Mrs. Brown's eyes and know that something true is being presented. Woolf says of good novelists that "the study of character becomes to them an absorbing pursuit; to impart character an obsession," but she also acknowledges that few novelists succeed in "catching" Mrs. Brown, "most have to be content with a scrap of her dress or a wisp of her hair" ("Mr. Bennett and Mrs. Brown" 94, 97).

To return to the moment of being, Woolf's description of the experience marks four (relatively) distinct phases: 1) The prior state of non-being through which the moment reveals itself; 2) the sudden shock, usually engendered by a visual stimulus 
and/or imaginative act; 3 ) the revelation in which the true thing behind appearances becomes known; and 4) the act of recalling and expressing the moment in order to "explain" it. Though Woolf makes the phases of the process clear in "A Sketch of the Past," what becomes apparent when examining the moment of being at work in her novels is that the moment is usually prompted by, revelatory of, and expressed through the issue of character, particularly when one character muses on the (im)possibility of knowing another. Woolf's most "susceptible" characters - Ralph Denham, Peter Walsh, and Lily Briscoe, for example - then become narrators themselves, shocked by a rupture in non-being provoked by a glimpse into another person's life, which they then pursue in the hopes of knowing, explaining, and expressing that shock and that person. In this way, these susceptible characters work through Woolf's larger epistemological concerns through the narrative and artistic issue of representation. In Night and Day, Woolf depicts the first two phases of the moment, in which non-being is interrupted by the sudden shock of a glimpse into the reality of another person, and gestures toward the possibility of revelation, but the revelation is confined within the terms of a love relationship. In Mrs. Dalloway, the attempt to connect with another person expands beyond an object of romantic attention to seek out possibilities for connections within a society fragmented by death and war. To the Lighthouse, then, enacts a kind of meta-moment through the artist's struggle with and eventual success in representing her "vision" of another, which alleviates the pain of loss by making a whole out of the severed parts of existence, by "making of the moment something permanent." 


\section{Night and Day}

When Woolf defines non-being and being in "A Sketch of the Past," she adds, "The real novelist can somehow convey both sorts of being ... I tried - in Night and Day" (70). ${ }^{2}$ According to Suzanne Raitt's introduction to Night and Day, this early exercise in conveying non-being came as a result of Woolf's dissatisfaction with the form of the novel after writing The Voyage Out; she felt she needed to master conventional forms before she could experiment with those more suited to her needs (xiv). Woolf had also suffered a mental and physical breakdown after finishing The Voyage Out (completed in 1913 and published in 1915) and wasn't well enough to write until 1916, even then only for an hour or so a day. She wrote Night and Day as a therapeutic exercise from 1916-1919, and was probably too fragile to undertake the immense social commentary and emotional exploration necessary to write a novel that acknowledged a post-war world. Instead, the world of the novel is compressed into a semi-Victorian microcosm and it adheres (at least superficially) to the conventional plot of a social comedy of romance, as it mainly addresses issues of romantic and familial relationships with nearly everyone coupling up in marriage at the end. For these reasons, Night and Day has been relatively overlooked in critical conversations about the moment of being, except when it is referred to as an illustration of non-being against which Woolf would define being in her later works. ${ }^{3}$ While the moment is not foregrounded in the same way as it would be in later novels, like Mrs. Dalloway, the novel is of particular significance in the oeuvre because it excavates the spaces where moments of being can occur. Jean

\footnotetext{
${ }^{2}$ Woolf also mentions The Years here as part of the project to convey both being and non-being, but my focus is on Night and Day mainly because of its early place in Woolf's novel-writing.

${ }^{3}$ For example, Meg Jensen's article on the moment of being in Virginia Woolf's major novels, which deals specifically with "tradition and revelation" in the moment, ignores Night and Day completely.
} 
Love expresses this aptly in Worlds in Consciousness when she argues that the novel has little to do with the farcical romance that the surface plot constitutes, but is instead "a novel about knowledge, even epistemology, and asks questions having both general philosophical implications and personal meaning for the characters in the charade" (109). But it is through this confined world and conventional plot that Woolf feels able to frame her larger philosophical questions.

Woolf highlights her epistemological concerns in writing Night and Day in the following excerpt from a 1919 letter to Janet Case:

....and then there's the whole question, which interested me, again too much for the books sake, I daresay, of the things one doesn't say; what effect does that have? and how far do our feelings take their colour from the dive underground? I mean, what is the reality of any feeling? - and all this is further complicated by the form, which must sit tight, and perhaps in Night and Day, sits too tight; as it was too loose in The Voyage Out. (Congenial Spirits 116)

In her explanation, non-being is the "dive underground" - what is unsaid, unshared, and thus unknown in human relationships - and it is contrasted by the ambiguous and unstable notion of "feeling." This dichotomy is addressed directly through the relationship between Katharine Hilbery, who perpetually dives underground to protect her solitude, and Ralph Denham, who constantly questions the reality of his felt connection with her, but it is also enacted on an even smaller scale within characters' individual consciousnesses. As the novel works toward the dialectical synthesis of Ralph and Katharine, Woolf questions the possibility of synthesis in the numerous central antitheses established throughout the novel - namely, subjective thought and objective 
reality, self and other, being and non-being, modernity and tradition, and of course, night and day.

The first two lines of the novel foreground the dichotomy of night and day, that is, what can and cannot be known about another person:

It was a Sunday evening in October, and in common with many other young ladies of her class, Katharine Hilbery was pouring out tea. Perhaps a fifth part of her mind was thus occupied, and the remaining parts leapt over the little barrier of day which interposed between Monday morning and this rather subdued moment, and played with the things one does voluntarily and normally in the daylight. (Night and Day 3)

The first line describes what anyone present at the tea party, in the "daylight" of objective reality, could say about Katharine Hilbery and the second could only be known by Katharine herself or someone with access to the depths of her subjective thought, like the omniscient narrator. Katharine is silent, but "evidently mistress" of this situation, choosing to act her part unconsciously "without bringing into play any of her unoccupied faculties"; she chooses to exist in a state of non-being in which she is completely disconnected from the tea party and its guests, automatically performing what's expected of her, and no one seems to require more. However, the unoccupied faculties of her mind are activated when she begins to imagine the perspective of an imaginary guest. "It suddenly came into Katharine's mind that if someone opened the door at this moment he would think that they were enjoying themselves"; the discrepancy of what the imagined person perceives and the reality of the situation makes her laugh and she absorbs herself back into the scene to say something "to increase the noise ... since she herself had not been feeling exhilarated" (3). 
The barrier between personal and social worlds becomes permeable when, "at the very same moment, rather to her amusement, the door was flung open, and a young man entered the room" (3). She seems to invite this character into her world and her immediate reaction is to test the fiction she has constructed against reality by "asking him, in her own mind, 'Now do you think we're enjoying ourselves enormously?"' (3). She continues to play this speculative game with the young man, sounding much like Woolf in "Mr. Bennett and Mrs. Brown" or the narrator of the earlier short story "An Unwritten Novel,"4 particularly when she notices his nervousness and thinks, "he probably disliked this kind of thing, and had come out of curiosity, or because her father had invited him - anyhow, he would not be easily combined with the rest" (5). The novel shifts to Ralph's perspective where he plays the same speculative game with her, observing (with remarkable insight) that it is "obvious to him that she attended only with the surface skin of her mind" (7). Katharine is briefly shocked out of her detached, solipsistic unconsciousness by Ralph Denham's entrance and the two immediately establish an imaginative connection which takes the form of this speculative interest in each other. The interest is engendered and kindled by sparks of mutual understanding, which Katharine then attempts to suppress and which Ralph pursues indefatigably. Woolf's philosophy of character-making as she explains it in "Mr. Bennett and Mrs. Brown" is then enacted through Ralph's romantic pursuit of Katharine, as he constantly tries to reconcile his illusion of her with reality and obsessively attempts to "account" for her, to use Woolf's term from the essay.

\footnotetext{
${ }^{4}$ The short story illustration of the railway car game Woolf refers to in "Mr. Bennett and Mrs. Brown" and elsewhere; first published in 1921 in the collection Monday or Tuesday.
} 
Though Katharine begins the novel using her imaginative faculties to narrate and to connect with Ralph, she suppresses her imagination guiltily throughout the novel, privileging reality and solitude above any illusion of knowing or being known by others. Katharine protects her solitude by partaking in unconscious activities like the tea party or assisting her mother with a biography of her poet-grandfather but, as the narrator divulges, "it would have been a surprise, not only to other people but to Katharine herself, if some magic watch could have taken count of the moments spent in an entirely different occupation from her ostensible one. Sitting with faded papers before her, she took part in a series of scenes," imagining herself taming wild ponies or conducting a ship through a storm, for example (41-42). Beyond that, and even more embarrassingly, "upstairs, alone in her room, she rose early in the morning or sat up late at night to ... work at mathematics" (Woolf's ellipsis); furtively and secretively, Katharine is then able to "concentrate her mind to the utmost" (42). Her imaginative moments are not what Woolf would describe as moments of being because they arise out of her need for control, her preferring "the exactitude, the star-like impersonality, of figures to the confusion, agitation, and vagueness of the finest prose" (42). We are told that she has an "antipathy to that process of self-examination, that perpetual effort to understand one's own feeling, and express it beautifully, fitly, or energetically in language" (40). These moments reinforce non-being, in fact, as Katharine deliberately resists examining her feelings and initially refuses to communicate them because in doing so she must share her real, conscious self with another. Throughout the novel, Katharine struggles to reconcile her fear of self-examination and communication with her feelings for and interest in other characters. 
Katharine's engagement to William Rodney is depicted as the ultimate protection from being. William embodies (at least in the beginning of the novel) the traditional, Victorian idea of marriage that merely requires Katharine to behave according to society's expectations of a woman and a wife. If she marries Rodney, she knows she can retain her mental independence and never be asked to divulge her real self. Katharine has imaginative flights in which she dreams of the presence of a love "drawing into it every drop of the force of life, and dashing them all asunder in the superb catastrophe in which everything was surrendered, and nothing might be reclaimed" (107-8), but the overwhelming surrender of selfhood to love (the love Ralph requires of her in the end) cannot be reconciled with Katharine's idea of reality, so she chooses instead to "contemplate a perfectly loveless marriage, as the thing one did actually in real life" (108). When she thinks of marrying Rodney and the seeming inevitability of their life together, she submerges herself into a "dream state," in which she puts to rest the possibility of shared happiness (144):

There dwelt the thing one might have felt, had there been cause; the perfect happiness of which here we taste the fragment; the beauty seen here in flying glimpses only ... It was a place where feelings were liberated from the constraint which the real world puts upon them; and the process of awakenment was always marked by resignation and a kind of stoical acceptance of facts. (144-5) Accepting non-being as her reality, she tells Rodney that she will marry him "like one sending a voice from sleep to reach the living ... in a voice so level, so toneless, so devoid of joy or energy" (145). Katharine's eventual refusal of Rodney, when she is able to acknowledge that she cannot continue on into a loveless marriage with him, is a 
rejection of non-being and an act of self-examination in which she surfaces from the underground of unreal feeling to communicate with another human being. She begins the "process of awakenment," not to resign herself to stoicism, but to embrace the philosophy (Dostoevsky's, in fact) which she can only half-consciously mutter earlier in the novel as she walks past Ralph on the Strand: "It's life that matters, nothing but life - the process of discovering - the everlasting and perpetual process, not the discovery itself at all" (132). According to Temira Pachmuss's article on Dostoevsky and Woolf, Katharine's repetition of this quotation from The Idiot reveals the shared "solemn message" of both authors' fiction, that "absolute freedom and loneliness always go hand-in-hand" (Pachmuss 422). Katharine can only surface from the underground of solitary non-being if she can learn to renounce her absolute freedom and share her real, imaginative self with another.

Ralph, unlike Katharine, is a narrator by nature, even by compulsion, who shares much of the voyeuristic pleasure Woolf illustrates in essays like "Street Haunting: A London Adventure"; when he leaves the Hilbery home, feeling powerless after his unsuccessful interaction with Katharine, he is consoled by the "glimpse which half-drawn curtains offered him of kitchens, dining-rooms, and drawing-rooms, illustrating with mute power different scenes from different lives, his own experience lost its sharpness" (Night and Day 18). He focuses his narrative attention on Katharine, who becomes for him the resistant character daring him to "catch" her, as Woolf says Mrs. Brown dares the novelist. Katharine, of course, has not dared him and wholeheartedly resists his efforts to know her, but Ralph becomes obsessed with the pursuit of her, as Woolf says any good novelist must be, but his early efforts are too proprietary, too dominating to be a good

\footnotetext{
${ }^{5}$ From Dostoevsky's The Idiot, first published serially in The Russian Messenger, 1868-1869.
} 
narrator or a good love match. In each encounter with Katharine, he revises or reconstructs the notion of her that he has constructed in her absence, and in doing so must eventually decide whether he prefers his dream of her or the reality of her presence. When Ralph visits Katharine alone for the first time and sits down with her in the drawing room, "His eyes were bright, and, indeed, he scarcely knew whether they beheld dreams or realities," and when he acknowledges her as a reality "there rose unchecked a joyful recognition of the truth that human nature surpasses, in its beauty, all that our wildest dreams bring us hints of" (149). While Katharine's moments of joy arise in the dreams and activities she keeps secret, Ralph experiences something like true moments of being when he is given insight into human nature. But when Ralph's illusions of Katharine are proven false in her presence, he is thrown into artistic despair by the inadequacy of his ability to represent her truthfully; "He had lost something in speaking to Katharine, for, after all, was the Katharine whom he loved the same as the real Katharine? ... He felt a mixture of disgust and pity at the figure cut by human beings when they try to carry out, in practice, what they have the power to conceive" (317). Here Ralph prefigures the narrator of "An Unwritten Novel," who must accept that the woman on the train is not the Minnie Marsh character she has imagined, and yet resolves to continue seeking the truth of character despite her lack of control over it.

Throughout the novel, Ralph enacts the narrative struggle to unite illusion with reality in order to understand and "catch" Katharine (eventually through marriage, the only sustainable intimate relationship this novel seems able to fathom). Katharine resists his efforts to narrate her, constantly tearing down his illusions of her and reminding him that she is real and therefore not as interesting as he imagines her to be. She asserts, 
I'm a matter-of-fact, prosaic, rather ordinary character: I order the dinner, I pay the bills, I do the accounts, I wind up the clock, and I never look at a book ... Being yourself very inexperienced and very emotional, you go home and invent a story about me, and now you can't separate me from the person you've imagined me to be. You call that, I suppose, being in love; as a matter of fact it's being in delusion. (402)

To Katharine, love is a fictional construct, a story-telling that distances one from the truth, but Ralph responds, "That may be what we have to face. There may be nothing else. Nothing but what we imagine" (402). When Ralph tries to rid himself of illusion, "to face her, and having steeped himself in her qualities, to convince his reason that they were, as she assured him, not those that he imagined" (405), he experiences a moment of absolute understanding in which illusion and reality are not mutually exclusive, but can finally merge in his imaginative representation of Katharine: "They seemed to pass in and out of each other's minds, questioning and answering ... they merged themselves in the flawless union that was born of their association. They surveyed life to its utmost limits. How deep it was when looked at from this height! How sublime!” (405). The great epistemological gap is bridged and, as it must within the confines of this novel's world, the revelation of knowledge is (however hesitantly) defined as love: "Some words of these reflections were uttered aloud, and it happened that among them were the words, 'I love her"” (406).

Ralph becomes aware of his feelings for Katharine when he is finally able to reconcile illusion with reality, but Katharine's revelation of love occurs when she loses the freedom of self she has protected so adamantly throughout the novel and begins to 
imagine Ralph herself, as she did in the novel's first scene. Katharine comes to see Ralph "more and more plainly" as she stands outside of his office in search of him and she comes to the realization that "more and more did he seem to her unlike anyone else" (463). At the moment of this acknowledgement, she awakens from her solipsistic state to narrate the scene in which Ralph would arrive at her house, be told that she was out, and walk away hurt by the dismissal; she imagines where he will walk next, but gives up because she feels "unable to cope with the strength of her own desires" (465). When she surrenders to those desires, she is overcome with a sense of meaning and reclaims a selfhood that has been made more valuable by its being shared with another:

No one but she herself knew what it meant to miss Ralph Denham on that particular night; into this inadequate event crowded feelings that the great crises of life might have failed to call forth. She had missed him, and knew the bitterness of all failure; she desired him, and knew the torment of all passion. It did not matter what trivial accidents led to this culmination. (471)

At the end of the novel, Katharine and Ralph are able to communicate, not in the language which has failed them time and again, as Woolf constantly reminds us that it must, but with symbols that truly represent their feelings for each other - Ralph's dot with flames and Katharine's algebraic symbols. In a conversation with her mother before she and Ralph decide to marry, Katharine denies the possibility of marriage because she cannot stand the thought of the constant uncertainty that marriage would force her to endure, always wondering whether her feelings and her conception of Ralph are real. Mrs. Hilbery allays her fears when she says, "We have to have faith in our vision" (50910). Katharine and Ralph are able to come to an understanding when they acknowledge 
the impossibility of ever truly knowing one another, but that it is the attempt at knowing that matters. "You'll find out that I'm not what you think me," Katharine says to Ralph, and he responds, "Perhaps. But I shall gain more than I lose" (402).

Dialectical synthesis, the marriage of opposites, is what the novel works towards from its title to its final lines. Ralph and Katharine achieve a kind of synthetic union in marriage, but only when they mutually acknowledge the illusory nature of their connection. They put their faith in a vision, which can be read as pessimistic and unsettling, but Hermione Lee validates the seeming instability of the ending because it "encourages the hope that some link can be forged between its silent and its communicable worlds" (Lee 65). Jean Love argues that although complete synthesis is eventually revealed to be impossible, "characterization is the most successful aspect of Night and Day and is its closest approximation of dialectic" (Love 107). Through the conventional marriage plot, the synthesis of a man and a woman in love, Woolf addresses the complexity of knowledge in its most intimate form to better equip herself to take on issues of the self's existence within the world-at-large, a world constantly reminding the individual of its mortality and transience, in her later novels. Night and Day does indeed ignore death and it dwells in moments of non-being more than any other of Woolf's novels, but it enacts on a small scale, in a traditional form and with a traditional plot, the central issues of her later more typically "modernist" works. The worlds of her subsequent novels could then expand to include the problems of human relationships on a societal scale in a world changed by death and war (in Mrs. Dalloway, for example). The novel is also significant in Woolf's oeuvre because, in its attempt to convey non-being through the lapses in human relationships, she was able to illustrate the first two phases 
of the experience of the moment of being (the non-being and the shock) and to glimpse at the possibilities made available to human character by the third, revelatory phase. The novel diacritically defines the moment of being against the more prevalent states of nonbeing and does so by illustrating the human interest in character, which in this novel takes the form of love, the most basic manifestation of the obsession with understanding and accounting for another human being.

\section{Mrs. Dalloway}

In her 1927 essay "The Narrow Bridge of Art," Woolf writes: "Every moment is the centre and meeting place of an extraordinary number of perceptions which have not yet been expressed" ("The Narrow Bridge of Art" 909); perhaps more than any other of her novels, Mrs. Dalloway (published in 1925) illustrates this philosophy. Woolf provides the meeting place for perception en masse in many moments, such as the car backfiring outside of the flower shop, the airplane sky-writing, as well as the tolling of bells marking literal moments, which all "attract consciousness to themselves" as a way of expressing unity, as Jean Love observes (Love 153). But perhaps even more significant than these moments of observational unity which come and go throughout the novel, Woolf embodies the meeting-place for many perceptions within the character of Clarissa Dalloway who, unlike the personless, sound-provoked moments, consistently attracts consciousness to herself and provides a stream of consciousness to the novel, bringing about unity for the novel as a whole, as well as for its many characters and its many moments. Mrs. Dalloway is a character for others to narrate and seek to know, but Woolf also makes us privy to the depths of her real self, to her own moments of being. For 
Woolf, as I have argued, expressing the reality of the moment and the reality of character are always bound up within each other, but in no other novel is the relationship made so explicit. In Mrs. Dalloway, the dialectic form of Night and Day expands into a complex network of consciousnesses which centers on the figure of Clarissa Dalloway, and this expansion beyond the romance plot's dialectic considerably raises the stakes. If the central question of Night and Day is "Can we ever really know another person," Mrs. Dalloway wonders "How can we even attempt to know others in the face of death, the ultimate disconnection?" Mrs. Dalloway becomes an emblem of connections - a hostess of being who, though she cannot avoid the reality of death, offers the chance to connect in spite of it.

Clarissa is foregrounded as the connective force and figure of being in the novel from its opening scene, in which her presence amongst a bustling mass of people known and unknown reveals to her why she continues "making it up, building it around one, tumbling it, creating every moment afresh," because it is what she loves, "life; London; this moment of June" (Mrs. Dalloway 4). As she stands looking at the omnibuses in Piccadilly, she experiences a heightened sense of perception and a unity with humankind so that she could not say of anyone that "they were this or they were that" and "she sliced like a knife through everything; at the same time was outside, looking in" (8). The simultaneous distance and connectedness that she feels brings on thoughts of her mortality and she wonders,

Did it matter that she must inevitably cease completely; all this must go on without her; did she resent it; or did it not become consoling to believe that death ended absolutely? but that somehow in the streets of London, in the ebb and flow of things, 
here, there, she survived, Peter survived, live in each other ... part of people she had never met; being laid out like a mist between the people she knew best, who lifted her on their branches as she had seen the trees lift the mist, but it spread ever so far, her life, herself. (9)

If Night and Day weaves the cotton wool of non-being and shows where it can be torn by the connection between two people, Mrs. Dalloway allows the moment to reveal the larger pattern, the true thing behind appearances on a societal level, in which the individual is not only connected to another in a moment of understanding, but to every life and place one touches, however briefly. Her theory of connectivity in the face of death is later recalled by Peter, who recalls that she explained it to him to combat their feeling of "dissatisfaction; not knowing people; not being known" (152). Clarissa explained that she ... felt herself everywhere; not 'here, here, here'...So that to know her, or any one, one must seek out the people who completed them; even the places. Odd affinities she had with people she had never spoken to, some woman in the street, some man behind a counter - even trees, or barns. It ended in a transcendental theory which, with her horror of death, allowed her to believe, or say that she believed (for all her scepticism), that since our apparitions, the part of us which appears, are so momentary compared with the other, the unseen part of us, which spreads wide, the unseen might survive, be recovered somehow attached to this person or that, or even haunting certain places after death ... perhaps-perhaps. (153)

I quote these passages at length because Clarissa's theory summarizes the novel's great philosophical project, to represent the acknowledgement of death and with it the 
dissolution of the self, but even more importantly, to offer solace and even transcendence through these moments of being-connected. To put it more succinctly, the self survives in being known by others, which is why solipsism (like that which Katharine tries to preserve in Night and Day) is the only real death.

On a narrative level, the novel works toward a complete knowledge of Clarissa through many perspectives so that, according to Woolf, "every scene would build up the idea of C's character. That will give it unity, as well as add to the final effect" (qtd. on Poresky 99). Clarissa's character is the unifying force, the being embodied, through which the many perspectives of the novel merge. Peter Walsh's perspective of Clarissa is the most prevalent and quite possibly the most profound because he, like Ralph Denham, is a natural narrator and Clarissa is his Katharine Hilbery, his Mrs. Brown. Like Ralph, when Peter interacts with Clarissa, he constantly compares the reality of her presence with his imagined version of her, but unlike Ralph, Peter's construction of Clarissa is based in his memories of actually knowing who she was years before. He spends his efforts throughout the novel trying to reclaim that connection with her in a way that merges his memory with the present in addition to merging illusion with reality. His sense of selfhood is directly related to his ability to characterize Clarissa, so when she eludes him (as she does after his first visit) his narrative impulse seeks a new object, a beautiful woman on the street whom he follows. Pursuing her and trying to discover traits or more ammunition for this process of characterization becomes a way to identify himself: "There was colour in her cheeks; mockery in her eyes; he was an adventurer, reckless, he thought, swift, daring, indeed (landed as he was last night from India) a romantic buccaneer" (53). Peter pursues character in order to define himself, because, as 
Jean Love argues, "The self is formed by the same processes that form other persons and objects in the conscious world and is differentiated out of the same whole - the primordial, diffuse experience of the world in reality" (Love 7). By selecting a person against whom he can define himself, and here the young woman stands in for Clarissa whom he feels disconnected from, Peter does not pursue knowledge of others, but knowledge of himself, which is why he fails to truly see Clarissa in her essence until the novel's end. The young woman enters her home and the connection is severed, which forces Peter to acknowledge that his vision has been "smashed to atoms," but he reminds himself that "one makes up the better part of life" (54). Through Peter Walsh and his attempts to "make up" Clarissa, Woolf expands the project of characterization, which was illustrated in Night and Day, to the "project of living," that is, characterization becomes integral to the feeling of being alive in the world (54).

Clarissa's party is the stage on which she will test her ability to merge many individual consciousnesses (as the backfiring car and sky-writing airplane did) and, in doing so, to transfix a moment and contribute to the "project of living." Her husband and Peter Walsh do not understand her urge to throw parties, Peter even considers them to be evidence of her superficiality, but she explains, "They're an offering” (121). Clarissa senses her role as the combinative, creative force and offers parties as an "attempt" (to use Lily Briscoe's term from To the Lighthouse) at making of the moment, of the multiplicity of selves, something unifying and therefore permanent. Her need to combine is set in direct opposition to the force of Conversion, the ultimate evil in this novel, which Clarissa attributes to love and religion and is embodied in the characters of Sir William Bradshaw and Doris Kilman. It can be said that conversion is what Ralph Denham 
initially tries to enact upon Katharine in Night and Day when he unsuccessfully tries to force Katharine to be what he has imagined. Peter Walsh seems to want to convert Clarissa to the woman he fell in love with, the kind of woman who wouldn't marry Richard Dalloway and throw parties. It can also be said that the narrator of "An Unwritten Novel" tries to convert the old woman she sees on the train into Minnie Marsh, but the project of understanding a character and another person requires a constant rejection of the human tendency to convert (through love, religion, etc.). Clarissa denounces Conversion as she observes the old woman whose window faces her own: "Why creeds and prayers and mackintoshes? when, thought Clarissa, that's the miracle, that's the mystery; that old lady, she meant, whom she could see going from chest of drawers to dressing-table. She could still see her. And the supreme mystery ... was simply this: here was one room; there another. Did religion solve that, or love?" (127). The solution Clarissa offers to protect the supreme mystery of Otherhood is to continue to make her offerings, even when it involves a dissolution of herself. For instance, when her party starts, she braces herself for the influx of guests and thinks,

And yet for her own part, it was too much of an effort. She was not enjoying it. It was too much like being - just anybody, standing there; anybody could do it; yet this anybody she did a little admire, couldn't help feeling that she had, anyhow, made this happen, that it marked a stage, this post that she felt herself to have become...Every time she gave a party she had this feeling of being something not herself, and that every one was unreal in one way; much more real in another. (170-71)

Despite the effort required of her to give these parties, she realizes that through them she makes it possible "to go much deeper." Clarissa becomes a symbol of the moment of 
revelation embodied when at her party Peter describes her as a mermaid, "lolloping on the waves and braiding her tresses she seemed, having that gift still; to be; to exist; to sum it all up in the moment as she passed" (174). For Peter and in another way for her party guests, Clarissa is the figure through which being becomes possible.

Septimus Warren Smith, on the other hand, connects with no one because his traumainduced madness prevents him from living in the present moment. War has made Septimus the embodiment of solipsism in that he is susceptible to profound feeling that approaches being, but his heightened perceptions do not reveal the pattern uniting him to others, allowing him to transcend beyond individuality and rootedness; instead, he turns inward. The self is never transcended, but descended into, and memory does not enliven or enrich the present moment, but usurps it. Thomas Caramagno, in his study of the effect of Woolf's manic-depressive illness on her fiction-writing, explains, "Septimus is aware of both kinds of knowledge - what he is perceiving objectively and what the perception means to him subjectively - but he is unable to connect or integrate them and so feel unified himself” (227). Unlike Clarissa, his double, Septimus is not mentally capable of merging, which as Caramagno notes, is why he has lost his sense of self. When he is then faced with the force of Conversion, Sir William Bradshaw, who prescribes "rest in solitude; silence and rest; rest without friends, without books, without messages" and thus threatens to sever the only connection he has left with his wife Rezia, he has no choice but to refuse Conversion and reclaim some sense of self and agency through suicide (Mrs. Dalloway 99). Septimus decides to give them "their idea of tragedy ... Holmes and Bradshaw like that sort of thing" (149), and when he sees Dr. Holmes he cries, "I'll give it you!" as a way of reclaiming his agency - in other words, "You cannot take this from 
me, I'll give it to you." He refuses to be separated from his wife and when Rezia sees what has happened, Woolf tells us that "she understood" (149). The shock that she feels is not grief, but becomes an imaginative experience in which she sees herself opening windows and stepping into a garden, and envisions a flag saluting men killed in battle. She reflects on all of their happy memories and says, "He is dead," and smiles, finally able to understand her husband. Septimus's illness in life prevented him from sustaining a connection with his wife, and so his suicide becomes the most profound possible "offering" of being in that he is not only able to communicate something vital about himself and his final act to his wife, but he also becomes irrevocably connected to, or to use Woolf's own poetics, laid out like a mist among people known and unknown.

The suicide then becomes another event in the novel that attracts consciousness to itself, communicating differently to different characters. As the ambulance rushes by Peter, he experiences a sympathetic moment of being, "in which things came together; this ambulance; and life and death" (152). Just as Septimus's suicide allows Rezia to finally understand him, when Clarissa hears of it she experiences the same profound understanding of the act even though she has never met him. She empathizes with him in morbid detail, undergoing the sensations of death she imagines he felt. At first, she cannot believe death has been introduced into her party, her offering to life, but then she understands what it was that Septimus meant when he threw himself out of the window: "A thing there was that mattered ... This he had preserved. Death was defiance. Death was an attempt to communicate; people feeling the impossibility of reaching the centre, which, mystically, evaded them; closeness drew apart; rapture faded, one was alone. There was an embrace in death" (184). She is not paralyzed by fear of death, but instead 
realizes its inevitability and acknowledges its presence; her thoughts return to her party, and she is glad that "he had done it; thrown it away ... he made her feel the beauty; made her feel the fun. But she must go back. She must assemble" (186). Jean Love describes it most poetically when she writes, "the suicide is a sacrament in which Clarissa partakes" (159-60); in other words, Septimus's suicide is an "attempt to communicate," or even more appropriately, an offering like Clarissa's party in which many people with their many perspectives have the opportunity to merge and connect, thus revealing the "real thing behind appearances" that unifies all of existence - death. In coming to terms with death and allowing Septimus's act to communicate with her own life, Clarissa enacts the transcendental theory she espoused to Peter earlier in the novel - that a person lives on both in people they know and those they have never met. She experiences a moment of being in which what is revealed validates her offering and her assembling, in spite of and even in resistance to death. The novel closes with the end of Clarissa's party, but more specifically with Clarissa literally coming into being through the perspective of Peter Walsh, who is filled with terror, ecstasy, and "extraordinary excitement" as he recognizes Clarissa in his own moment of being: "For there she was" (194). While Night and Day mainly investigates the possibilities for brief moments of connection surrounded by the more prevalent lapses of non-being, Mrs. Dalloway is a much more nuanced exploration of being. The novel depicts a network of consciousnesses rising and falling in moments of awareness, all working toward the revelation which To the Lighthouse would then attempt to express and therefore crystallize, that despite our momentary, temporary apparitions on this earth, the unseen parts of us survive in the connections we have made and in the moments we have experienced. 


\section{To the Lighthouse}

Mark Hussey, in The Singing of the Real World, observes that in Night and Day the world that emerges "is one in which any relationship that is not an illusion seems quite impossible," and that Mrs. Dalloway continues the theme of "the failure of relationships, specifically of love, to "make of the moment something permanent"' (Hussey 46, 48). If this is true, then To the Lighthouse (1927) recognizes the illusory nature of knowledge of others, embraces the failures of relationships for what they attempt, and seeks to express this attempt through the moment which, as Woolf says, is what makes it real. The pursuit of character enacted throughout Woolf's fiction reaches its climax in To the Lighthouse, but it is no longer just a railway car game; in this novel, the project of representing character becomes an urgent attempt to cope with mortality and to recover something of what has been lost. The novel is itself a meta-moment culminating in a completed vision; Woolf expresses the full experience and vision of the moment by depicting an artist's attempt to represent the moment of being. To put it more clearly, Lily Briscoe's successfully rendered vision of Mrs. Ramsay "makes of the moment something permanent" in that the moment, and with it Mrs. Ramsay, is recalled and resurrected from the past. Whether or not Lily's painted vision of Mrs. Ramsay is thrown in an attic or destroyed matters little to her because the "attempt" (like Clarissa's "offering") at knowing is the ultimate act, capable of transcending even death. Like Clarissa Dalloway's theory of living on after death by being spread out like a mist amongst the people and places that she has known, Lily Briscoe's painting allows the essence of Mrs. Ramsay to survive. Ultimately, Woolf's novelistic rendering of her mother through the 
character of Mrs. Ramsay allows her to understand and finally cope with her mother's untimely death.

In "Reminiscences," Woolf describes her mother's power of elevating experience to scenes and people to characters - "She stamped people with characters at once...she drew out...such sparks of character as they have never shown to anyone since. All lives directly she crossed them seemed to form themselves into a pattern and while she stayed each move was of the utmost importance" ("Reminiscences" 35). Like Julia Duckworth Stephen and Clarissa Dalloway, Mrs. Ramsay is the foundation from which others derive their identities; she gives of herself, quite literally, to her husband, her children, and her house guests so that they may feel more whole, integrated into the pattern of lives which centers of Mrs. Ramsay. While Mrs. Dalloway merges and combines through her self and her party, Mrs. Ramsay, like Woolf's mother, sympathizes and sacrifices, and this aspect of her character becomes associated with the figure of the lighthouse. Her first words and actions in the novel are directed in sympathy toward the lighthouse; first, she sympathizes with James in being denied his trip to the Lighthouse (because Mr. Ramsay is unable to sympathize), and later she asks her children,

For how would you like to be shut up for a whole month at a time, and possibly more in stormy weather, upon a rock the size of a tennis lawn? she would ask ... to see the same dreary waves breaking week after week, and then a dreadful storm coming, and the windows covered with spray, and birds dashed against the lamp, and the whole place rocking, and not be able to put your nose out of doors for fear of being swept into the sea? (5) 
What begins as an address meant to admonish her children for their selfishness becomes a narrative exercise in which she nearly becomes absorbed in it to the point of catastrophe, much like the narrator of "An Unwritten Novel." Mrs. Ramsay is a kind of narrator herself, an imaginer of others, but her imaginative acts are extensions of her sympathy, not creative acts, at least not in the artistic sense. Her dinner and opening her home to guests can be interpreted as types of creative acts, however, since she uses her natural acumen as hostess and mother-figure to create something lasting. Reflecting on her dinner party, she thinks, "The event had given her a sense of movement. All must be in order ... Yes, that was done then, accomplished; and as with all things done, became solemn" (113). And because she has been able to solemnify the moment, "They would, she thought, going on again, however long they lived, come back to this night; this moon; this wind; this house: and to her too" (113). She has literally gone through the process of making the moment permanent, and in doing so, has made herself permanent: "It flattered her, where she was most susceptible of flattery, to think how, wound about in their hearts, however long they lived she would be woven; and this, and this, and this, she thought ... would be revived again in the lives of Paul and Minta" (113). The mention of Paul and Minta as a reincarnation of the moment, is particularly noteworthy because it portrays Mrs. Ramsay's marriage scheming as a way of ensuring some kind of permanence for herself; she thinks, "Paul and Minta would carry it on when she was dead" (114). Mrs. Ramsay also experiences a feeling of "security" at the dinner table when she thinks of Lily and Mr. Bankes marrying, "Nothing need be said; nothing could be said. There it was, all round them...there is a coherence in things, a stability ... Of such moments, she thought, the thing is made that endures" (105). Where Clarissa Dalloway offers parties, 
Mrs. Ramsay offers her home in the hopes that something will be made which endures, like a marriage.

The only character with anything resembling Mrs. Ramsay's level of sympathetic intuition is Lily Briscoe, whose struggle throughout the novel embodies the epistemological dilemma of the narrator-artist-observer:

She could see it all so clearly, so commandingly, when she looked: it was when she took her brush in hand that the whole thing changed ... Such she often felt herself - struggling against terrific odds to maintain her courage; to say: 'But this is what I see; this is what I see,' and so to clasp some miserable remnant of her vision to her breast, which a thousand forces did their best to pluck from her. (19) The object of her observation and the subject of her painting is Mrs. Ramsay, whom she tries to represent reading to James outside of their home. Though Lily constantly observes Mrs. Ramsay and understands her state of mind without need of words (which even Mr. Ramsay is not consistently capable of), her intuition is not sufficient to move her from conception to expression in art or in life. She is overwhelmed by her feelings for Mrs. Ramsay in that particular moment, but when she tries to communicate (by picking up her brush), she cannot find the words to represent the truth of her emotion: “'I'm in love with you?' No, that was not true. 'I'm in love with this all,' waving her hand at the hedge, at the house, at the children. It was absurd, it was impossible" (19).

So much in this novel depends upon observation, from human relationships to the reality of existence. For example, Mr. Ramsay’s work, as it is explained to Lily by his son, is on "'Subject and object and the nature of reality'...'Think of a kitchen table then,' he told her, 'when you're not there"' (23). In response, Lily conjures a phantom kitchen 
table in great detail, and in doing so proves that she is capable of comprehending the existence of a thing independent of its physical presence. Lily recognizes like Ralph Denham and Katharine Hilbery that "reality" is a construct and it is the imaginative work of the artist, whether she paints or writes, to represent what is not physically present and to both recreate and mediate some perception of reality. Representing the reality of a moment, a character, the kitchen table, and a painting are all part of the same project, but Lily's role as painter allows Woolf to objectify and make accessible the process of creation. Herta Newman expresses this artistic-novelistic parallel aptly in Virginia Woolf and Mrs. Brown: "In struggling with the proportions of her painting, Lily reconstructs in the most palpable terms the pursuit of Mrs. Ramsay's essence and the unfolding process of the novel itself" (Newman 88).

Lily has a general interest in character outside of her connection with Mrs. Ramsay and most of her moments of being reveal some great truth about a particular character or about relationships as a whole. For example, a movement of William Bankes's hand triggers a perception overload, in which "the load of her accumulated impressions of him tilted up, and down poured in a ponderous avalanche all she felt about it ... She felt herself transfixed by the intensity of her perception" (To the Lighthouse 24). In this moment and in this ecstasy of perception, she understands and validates him as a person, but the ecstasy is checked by some less positive, realistic reminders of his behavior, and she despondently wonders how it is that people are able to know others at all: "How then did it work out, all this? How did one judge people, think of them? How did one add up this and that and conclude that it was liking one felt, or disliking? And to those words, what meaning attached, after all?" (24). Being a susceptible kind of person like Woolf 
(whom she, of course, is based on), Lily's impressions overwhelm her so that she moves from an interest in one single human being to a philosophical questioning of epistemology, and finally to an unraveling of the very nature of communication, language, and meaning. Lily then muses on the central issue taken up in Night and Day, the impossibility of knowing someone completely because one can never have access to their private thoughts, to the self who speaks to the self.

She imagined how in the chambers of the mind and heart of the woman who was, physically, touching her, were stood, like the treasures in the tombs of kings, tablets bearing sacred inscriptions, which if one could spell them out, would teach one everything, but they would never be offered openly, never made public ... Could loving, as people called it, make her and Mrs. Ramsay one? for it was not knowledge but unity that she desired, not inscriptions on tablets, nothing that could be written in any language known to men, but intimacy itself, which is knowledge.

Lily exposes the issue of relationships underlying the traditional comic-romantic plot of Night and Day; it is not love that any of the main characters seek, but knowledge. Love in Night and Day is a placeholder for knowledge and marriage is the medium through which to gain that knowledge, but Lily wonders "what art was there" (my emphasis) that would allow her to become "like waters poured into one jar, inextricably the same, one with the object one adored?" (51). The process of Lily's existential interrogations follows Woolf's own process of experiencing and coming to understand moments of being - the non-being of not understanding, the shock of awareness, and the revelation (like Peter Walsh's "For there she was"), but at this point Lily is unable to 
comprehend the revelation because she cannot express it. At this point in the novel, there is no art through which Lily can become one with her object, Mrs. Ramsay. Mrs. Ramsay, like the kitchen table (to use the crudest and most direct analogy), can only be recalled and represented when she is no longer there.

The "Time Passes" section begins by evacuating the house of the characters who previously filled it and obliterating perceivable identity - "Not only was furniture confounded; there was scarcely anything left of body or mind by which one could say, 'This is he' or 'This is she'" (126). The section also negates the questions that the characters have asked throughout the novel so far: "Almost it would appear that it is useless in such confusion to ask the night those questions as to what, and why, and wherefore, which tempt the sleeper from his bed to seek an answer" (128). These questions were asked specifically by Mrs. Ramsay in the previous section and we are immediately told that she has "died rather suddenly the night before" (128). This middle section of the book, its literal center, is a void in which human beings can only be detected by their sheddings, their corpses, and what they've left behind. "What people had shed and left - a pair of shoes, a shooting cap, some faded skirts and coats in wardrobe - those alone kept the human shape and in the emptiness indicated how once they were filled and animated" (129). There is little to observe or be observed in the section except for the horrifying inhuman gaze of nature, which watches the passage of time and the loss of lives, the flowers "standing there, looking before them, looking up, yet beholding nothing, eyeless, and so terrible" (135). Mrs. McNab's presence is the only force of resistance, which she enacts most poignantly in remembering Mrs. Ramsay. She recalls Mrs. Ramsay in different domestic scenes and even narrates what Mrs. Ramsay 
would say and do in that moment: "She could see her now, stooping over her flowers; and faint and flickering, like a yellow beam or the circle at the end of a telescope, a lady in a grey cloak, stooping over her flowers, went wandering over the bedroom wall, up the dressing-table, across the wash-stand, as Mrs. McNab hobbled and ambled, dusting, straightening” (136). Mrs. Ramsay recovers a life of her own through Mrs. McNab's memorial reincarnation of her and she is given a more literal presence in the beam of the lighthouse, but her presence, like the beam, is faint, flickering, and distant. The end of the section heralds the return of life to the home and the image on which it closes is Lily emerging from the world of non-being as she "clutched at her blankets as a faller clutches at the turf on the edge of a cliff. Her eyes opened wide. Here she was again, she thought, sitting bolt upright in bed. Awake" (143).

The final section opens on the household preparing for the long-awaited excursion to the lighthouse; it is a scene that emphasizes the disconnections of non-being in Mrs. Ramsay's absence by picking up where it left off. Mrs. Ramsay knew what to send to the people in the lighthouse, Nancy does not; Mrs. Ramsay sympathized with and sacrificed for Mr. Ramsay, Lily cannot. Mr. Ramsay directs his gaze at Lily as she paints, demanding of her what he demanded of Mrs. Ramsay, but she pretends not to notice him and he moves on, muttering "Alone" and "Perished" (147). In Lily's mind, the words "became symbols ... If only she could put them together, she felt, write them out in some sentence, then she would have got at the truth of things" (147), but Lily is a hesitant narrator, afraid to lift her eyes from the easel to look at him and to "look at life." She focuses on his boots, which literally do not require her looking at him and, like the details 
of the Edwardian novelists, are the safe point of narration - the "sunny island where peace dwelt, sanity reigned, and the sun for ever shone, the blessed island of good boots" (154).

As Mr. Ramsay leaves for the expedition to the lighthouse, Lily watches him go, with James and Cam sulkily following him, and then tries to return to her painting, which is a return to the original unfinished vision of the first section, but she is unable to make the first mark. The potential of representation makes her brush tremble "in a painful but exciting ecstasy ... Still the risk must be run; the mark made" (157). As she marks the canvas, she senses a "dancing rhythmical movement, as if the pauses were one part of the rhythm and the strokes another, and all were related" and in this sense she experiences an artistic moment of being, a seeing of the pattern behind the pauses and strokes of human relations (or of the beams of the lighthouse) (158). Her painting becomes a process of remembering and as she reflects on Mrs. Ramsay, she asks,

What is the meaning of life? ... The great revelation perhaps never did come. Instead there were little daily miracles, illuminations, matches struck unexpectedly in the dark; here was one ... Mrs. Ramsay bringing them together; Mrs. Ramsay saying, 'Life stand still here'; Mrs. Ramsay making of the moment something permanent (as in another sphere Lily herself tried to make of the moment something permanent) - this was of the nature of a revelation. In the midst of chaos there was shape. (161)

This revelation of what she owes to Mrs. Ramsay, which is that the moment she tries to represent exists at all because Mrs. Ramsay has made it something lasting in her mind, makes her feel "the discomfort of the sympathy which she held undischarged" in refusing to give Mr. Ramsay the sympathy he needed, as Mrs. Ramsay would have done. She 
walks away from her easel to try to see if Mr. Ramsay, James, and Cam had set sail; she cannot see clearly, but she sees one boat set apart from the others with its sail being hoisted that moment, she "decides" that it is their boat, and she begins to narrate what she imagines to be their experience: "Now they had got the sail up; now after a little flagging and hesitation the sails filled and, shrouded in profound silence, she watched the boat take its way with deliberation past the other boats out to sea" (162). The narrative immediately shifts to the lighthouse expedition party in the boat, as though travelling with Lily's imagination, and she discharges the sympathy she failed to provide by imagining the three people on the boat; in this way, the expedition to the lighthouse then becomes a narrative exercise in representing character truthfully. This seems to hold true as what evokes Lily's sympathy the most, James and Cam being "tragically" forced to bend to their father's will, is what the narrative begins with at the precise moment when she felt that sympathy for them, that is, it accounts for the moment they emerged from the house in misery and walked behind their father to the boat (163). The narrative even represents the great tragedy that Lily felt it was for them to be forced by their father to take this trip, by saying, for example, that James and Cam had a silent "compact to fight tyranny to the death ... Their grievance weighed them down. They had been forced; they had been bidden" (164-65). But the narrative gets progressively more sympathetic with Mr. Ramsay, as they move toward the lighthouse and Lily discharges her sympathy by simultaneously narrating and painting. Mr. Ramsay's presence initially prevented her from painting because she could not create symmetry or balance with him demanding of her what he demanded of his wife. But when she gains some perspective distance and acknowledges that she does not know him after all, she is able to have her vision and 
represent it truthfully and artistically. Narration, for Lily as it is for Woolf, becomes an attempt at knowing, "this making up scenes about them, is what we call 'knowing' people, 'thinking' of them, 'being fond' of them! Not a word of it was true; she had made it up; but it was what she knew them by all the same" (173).

As she simultaneously imagines the lighthouse expedition and paints, she thinks again of Mrs. Ramsay and of mortality - as Levenson so aptly puts it, "Lily remembers in order to paint and paints in order to remember" (Levenson 209). Confronted with mortality - Mrs. Ramsay's, her own, everyone's - she turns to art, embodied by the inscrutable poet Augustus Carmichael, for solace: "She looked at her picture. That would have been his [Augustus Carmichael's] answer, presumably - how 'you' and 'I' and 'she' pass and vanish; nothing stays; all changes; but not words, not paint," and she realizes that what her painting attempts, "remained for ever," (179). This discovery provides her with a feeling of power in this moment of being, a power over death in her ability to create art, fill space, and recall Mrs. Ramsay in spite of her death. Hermione Lee rephrases this revelation powerfully when she writes, "Without creative actions there is only space, like the space caused by death" (Lee 134).

As they near the Lighthouse, James and Cam do indeed feel more sympathetic towards their father. They watch him as they are about to reach the lighthouse island, wondering, "What do you want? they both wanted to ask. They both wanted to say, Ask us anything and we will give it you" (echoing Septimus Warren Smith's last words, perhaps) (207). Their act of observing and sympathizing is simultaneous with their reaching the lighthouse as Lily Briscoe decides, "He must have reached it"; she recognizes, echoing James and Cam's words, that "whatever she had wanted to give him, 
when he left her that morning, she had given him at last" (208). She says aloud, "It is finished," and then returns to her picture,

There it was - her picture. Yes, with all its greens and blues, its lines running up and across, its attempt at something. It would be hung in the attics, she thought; it would be destroyed. But what did that matter? she asked herself, taking up her brush again. She looked at the steps; they were empty; she looked at her canvas; it was blurred. With a sudden intensity, as if she saw it clear for a second, she drew a line there, in the centre. It was done; it was finished. Yes, she thought, laying down her brush in extreme fatigue, I have had my vision. (209)

What she sees clearly and represents with the line, to unblur her canvas and repopulate the steps, is Mrs. Ramsay - that is, the essence of Mrs. Ramsay, who is the Lighthouse herself, a central line holding the entirety of the scene, the vision, Lily's sense of self, and the novel together. Lily Briscoe is finally able to represent Mrs. Ramsay artistically and to thus enact Clarissa Dalloway's transcendent theory by recovering that "unseen part" of Mrs. Ramsay which survives through her husband, the house, and her children, just as Woolf is able to represent her mother, to know and understand her as a person and a character in her life story, through this novel. The two visions are completed simultaneously with the arrival at the lighthouse.

In "A Sketch of the Past," Woolf describes the therapeutic act of writing To the Lighthouse as follows: "I suppose that I did for myself what psycho-analysts do for their patients. I expressed some very long felt and deeply felt emotion. And in expressing it I explained it and then laid it to rest. But what is the meaning of 'explained' it?" (81). Thomas Caramagno conjectures, "Writing fiction was good therapy for Woolf because, 
like bipolar integration, fiction deals with subject-object transactions that make a whole, a meaning that ratifies the integrity of both self and text" (75). Michael Levenson observes that subject and object achieve a kind of liberation on the canvas as Lily creates "something which is neither of the world nor of the self but a third thing composed in their mutual unveiling" (178). This "third thing," I would argue, is the moment made permanent - a moment of being "explained" and thus made whole, in that it merges self with represented Other in a way that affirms selfhood as well as the self's existence within a larger world. According to Louise Poresky, among others, To the Lighthouse represents a culmination of the search for selfhood represented by the completed vision; the novels that follow it further explore the self (Orlando), illustrate its unsustainability (The Waves) or demonstrate its dissolution (The Years and Between the Acts).

Lily has "written" or painted what the narrator of "An Unwritten Novel" was unable to accomplish in the short story. This writtenness, the having of her "vision," is a moment of being made permanent through a profound act of empathy and aesthetic creation and, as Mark Hussey reminds us, is perpetually being recreated, tumbled down and built up again, in the act of reading (80-81). For Woolf, the moment of being was far more than a literary device for fabricating a sense of unity and completeness in her novels; the moment of being was the medium through which she could express how she experienced the world and why she wrote fiction; recreating moments of being allowed Woolf to explain her own susceptibility, integrating self, other, and text in a way that makes a whole. Perhaps even more significantly, representing the moment of being as it is experienced by her characters allows Woolf to crystallize and thus explain those "little daily miracles, illuminations, matches struck unexpectedly in the dark" and, like Mrs. 
Ramsay and Lily, to create shape in the midst of the chaos of life and death. To the Lighthouse then metafictionally accomplishes what Woolf works toward in Night and Day and Mrs. Dalloway; through Lily's attempt to alleviate the pain of loss (the lapses inherent in existence), it makes of those privileged moments something permanent, something that endures and communicates as it is read, for, as Woolf writes in "A Sketch of the Past," "they would not survive entire so many ruinous years unless they were made of something permanent; that is a proof of their "reality"' (142). 


\section{Works Cited}

Bennett, Joan. Virginia Woolf: Her Art as a Novelist. Cambridge: Cambridge University Press, 1964. Print.

Caramagno, Thomas C. The Flight of the Mind: Virginia Woolf's Art and ManicDepressive Illness. Berkeley and Los Angeles: University of California Press, 1992. Print.

Hussey, Mark. The Singing of the Real World: The Philosophy of Virginia Woolf's Fiction. Columbus: Ohio State University Press, 1986. Print.

Jensen, Meg. "Tradition and Revelation: Moments of Being in Virginia Woolf's Major Novels." The Cambridge Companion to the Modernist Novel. Ed. Morag Shiach. Cambridge: Cambridge University Press, 2007. Web.

Lee, Hermione. The Novels of Virginia Woolf. London: Methuen \& Co Ltd., 1977. Print. Levenson, Michael. Modernism and the Fate of Individuality: Character and Novelistic Form, from Conrad to Woolf. Cambridge: Cambridge University Press, 1991. Print.

Love, Jean O. Worlds in Consciousness: Mythopoetic Thought in the Novels of Virginia Woolf. Berkeley, Los Angeles, and London: University of California Press, 1970. Print.

Newman, Herta. Virginia Woolf and Mrs. Brown: Toward a Realism of Uncertainty. New York and London: Garland Publishing, Inc., 1996. Print.

North, Michael. Reading 1922: A Return to the Scene of the Modern. Oxford: Oxford University Press, 2001. Print.

Pachmuss, Temira. "Dostoevsky, Werfel, and Virginia Woolf: Influences and Confluences.” Comparative Literature Studies 9.4 (1972): 416-429. Web. 
Poresky, Louise A. The Elusive Self: Psyche and Spirit in Virginia Woolf's Novels. Newark: University of Delaware Press, 1981. Print.

Raitt, Suzanne. Introduction. Night and Day. Oxford: Oxford University Press, 2009. Print.

Schulkind, Jeanne. Introduction. Moments of Being. Ed. Jeanne Schulkind. San Diego, New York, London: Harcourt, Inc., 1985. 11-24. Print.

---. Congenial Spirits: The Selected Letters of Virginia Woolf. Ed. Joanne Trautmann Banks. San Diego, New York, London: Harcourt Brace Jovanovich, 1989. Print. ---. “Mr. Bennett and Mrs. Brown." The Captain's Death Bed and Other Essays. San Diego: Harcourt Brace Jovanovich, 1944. 94-119. Print. ---. Mrs. Dalloway. San Diego, New York, London: Harcourt, Inc., 1981. Print. ---. "The Narrow Bridge of Art." Modernism: An Anthology. Ed. Lawrence Rainey. Mailden, MA and Oxford: 2005. 903-909. Print. ---. Night and Day. Oxford: Oxford University Press, 2009. Print.

---. "Reminiscences.” Moments of Being. Ed. Jeanne Schulkind. San Diego, New York, London: Harcourt, Inc., 1985. 25-59. Print.

---. "A Sketch of the Past." Moments of Being. Ed. Jeanne Schulkind. San Diego, New York, London: Harcourt, Inc., 1985. 61-159. Print.

---. To the Lighthouse. San Diego, New York, London: Harcourt, Inc., 1981. Print. ---. “An Unwritten Novel.” A Haunted House and Other Stories. San Diego, New York, London: Harcourt, Inc., 1972. 8-21. Print. 